\title{
EFEK PEMBERIAN KOMBINASI SIPROFLOKSASIN DAN A-MANGOSTIN SECARA IN VITRO TERHADAP ERADIKASI UROPATOGEN ESCHERICHIA COLI
}

\author{
Maya Dian Rakhmawatie ${ }^{1}$, Afiana Rohmani ${ }^{2}$ \\ 1. Bagian Farmakologi Fakultas Kedokteran Muhammadiyah Semarang
}

2. Bagian Histologi dan Imunologi Fakultas Kedokteran Universitas Muhammadiyah Semarang

Korespondensi mayapriambodo83@gmail.com

\begin{abstract}
ABSTRAK
Latar Belakang Persentase resistansi Escherichia coli (E. coli) pada pasien ISK terhadap siprofloksasin mencapai 73.04\%. Berbagai usaha untuk memaksimalkan penggunaan antibiotika telah dilakukan, termasuk mengoptimalkan parameter farmakokinetika/farmakodinamika (PK/PD) dari masing-masing antibiotika. Dibutuhkan usaha lain untuk mengoptimalkan pengobatan menggunakan antibiotika yang telah tersedia, salah satunya mengkombinasikan dengan menggunakan senyawa yang berasal dari herbal, misal senyawa aktif a-mangostin.
\end{abstract}

Tujuan Penelitian Penelitian ini bertujuan untuk melihat efek pemberian kombinasi siproflokasin dan á-mangostin terhadap eradikasi uropatogen E. coli (UPEC).

Metode Penelitian Penelitian ini dilakukan dengan memberi perlakuan terhadap bakteri uropatogen E. coli (UPEC) secara in vitro. Perlakuan dibagi menjadi (a) kelompok perlakuan menggunakan kadar siprofloksasin $\mathrm{C}_{\max }$ pada dosis $500 \mathrm{mg}(2,4 \mu \mathrm{g} / \mathrm{mL})$, (b) kelompok perlakuan menggunakan kadar siprofloksasin $\mathrm{C}_{\text {max }}$ pada dosis $750 \mathrm{mg}(4,3 \mu \mathrm{g} / \mathrm{mL})$, (c) kelompok perlakuan menggunakan kadar siprofloksasin 2,4 $\mu \mathrm{g} / \mathrm{mL}$ dan a-mangostin kadar $0,18 \mu \mathrm{g} / \mathrm{mL}$, (d) kelompok perlakuan menggunakan kadar siprofloksasin $4,3 \mu \mathrm{g} / \mathrm{mL}$ dan a-mangostin $0,18 \mu \mathrm{g} / \mathrm{mL}$.

Hasil penelitian menyatakan bahwa pemberian kombinasi siprofloksain dan á-mangostin dapat mencegah pertumbuhan bakteri uropatogen $E$. coli pada strain resisten siprofloksasin (nilai MIC $128 \mu \mathrm{g} / \mathrm{mL}$ ) dibandingkan dengan pemberian siprofloksasin saja, namun efek tersebut tidak signifikan. Untuk uropatogen E. coli sensitif (MIC 0,008 $\mu \mathrm{g} / \mathrm{mL}) \mathrm{dan}$ intermediat (MIC 0,5 $\mu \mathrm{g} / \mathrm{mL}$ ), tidak terdapat perbedaan efek penurunan jumlah koloni atau eradikasi antara pemberian kombinasi siprofloksasin dan á-mangostin dengan pemberian siproflokasin tunggal.

Kesimpulan Pemberian á-mangostin dengan kadar $0,18 \mu \mathrm{g} / \mathrm{mL}$ yang dikombinasikan dengan siprofloksasin tidak memberikan manfaat nyata dalam eradikasi uropatogen E. coli, yang diuji secara in vitro.

Kata kunci : Siprofloksasin, a-mangostin, uropatogen E. coli 


\section{ABSTRACT}

Background The percentage of resistance Escherichia coli (E. coli) in patients with UTI to ciprofloxacin reached 73.04\%. Various attempts to maximize the use of antibiotics have been done, including optimizing the parameters pharmacokinetics/pharmacodynamics (PK / PD) of each antibiotic. Another effort is needed to optimize the use of antibiotic treatment that has been available, one of which combines the use of compounds derived from herbs, eg active compounds a-mangostin.

Objective The purpose of this study is to find the effect of the combination of á-mangostin and ciprofloxacin on uropathogen E. coli (UPEC) eradication.

Methods This research was carried out by treating the bacteria uropathogen E. coli (UPEC) in vitro. Treatment is divided into (a) treatment groups using ciprofloxacin concentration $\mathrm{C}_{\max }$ at $500 \mathrm{mg}$ dose $(2,4 \mu \mathrm{g} / \mathrm{mL})$, (b) treatment groups using ciprofloxacin concentration $\mathrm{C}_{\max }$ at $750 \mathrm{mg}$ dose $(4,3 \mu \mathrm{g} / \mathrm{mL})$, (c) treatment groups using ciprofloxacin concentration $2,4 \mu \mathrm{g} / \mathrm{mL}$ and a-mangostin concentration $0,18 \mu \mathrm{g} / \mathrm{mL}$, (d) treatment groups using ciprofloxacin concentration $4,3 \mu \mathrm{g} / \mathrm{mL}$ and a-mangostin concentration $0,18 \mu \mathrm{g} / \mathrm{mL}$.

Result states that a combination of á-mangostin and ciprofloxacin can prevent the growth of uropathogen $E$. coli ciprofloxacin-resistant strains (MIC value of $128 \mu \mathrm{g} / \mathrm{mL}$ ) compared to administration of ciprofloxacin alone, but the effect was not significant. On uropathogen $E$ coli sensitive to ciprofloxacin (MIC 0,008 $\mu \mathrm{g} / \mathrm{mL}$ ) and intermediate (MIC $0,5 \mu \mathrm{g} / \mathrm{mL}$ ), there was no difference effect of decreasing the number of colonies between awarding a combination of ciprofloxacin and á-mangostin compared administering ciprofloxacin only.

Conclusion Provision of á-mangostin grading $0,18 \mu \mathrm{g} / \mathrm{mL}$ combined with ciprofloxacin had no real benefit in eradicating uropathogen $E$. coli, which is tested in vitro.

Keyword : ciprofloxacin, a-mangostin, uropathogen E. coli

\section{PENDAHULUAN}

Resistensi bakteri terhadap berbagai golongan antibiotika meningkat, sementara pengembangan antibiotika terkendala waktu dan biaya yang besar. Oleh karena itu, diperlukan optimalisasi penggunaan antibiotika yang tersedia ${ }^{1}$. Resistensi juga terjadi pada siprofloksasin yang digunakan untuk pengobatan infeksi saluran kemih (ISK), suatu infeksi yang cukup banyak diderita oleh manusia. Sebanyak 40-50\% wanita usia dewasa pernah mengalami ISK dalam periode hidupnya ${ }^{2}$. Menurut Mandal et al. (2012), persentase resistansi Escherichia coli (E. coli) pada pasien ISK terhadap siprofloksasin telah mencapai $73,04 \%$.

Berbagai usaha untuk memaksimalkan penggunaan antibiotika telah dilakukan, termasuk mengoptimalkan parameter farmakokinetika / farmakodinamika (PK/PD) dari masing-masing antibiotika tersebut ${ }^{4}$. Namun, beberapa penelitian menunjukkan bahwa optimalisasi parameter PK/PD tidak sepenuhnya dapat mengurangi kejadian resistensi antibiotika. Penelitian Rakhmawatie (2012) yang menggunakan model simulasi kinetika in vitro, melihat pengaruh siproflokasin terhadap resistensi bakteri uropatogen E. coli. Hasil penelitian menunjukkan terjadi penurunan jumlah bakteri pada 2 jam pertama pemberian siprofloksasin dosis $750 \mathrm{mg}$ yang berbeda secara signifikan dibandingkan pemberian siprofloksasin dosis $500 \mathrm{mg}$. Namun setelah perlakuan 3 hari, kedua kelompok perlakuan membentuk bakteri uropatogen E. coli yang resisten ${ }^{5}$.

Eradikasi dan terbentuknya bakteri $E$. coli yang resisten selain dipengaruhi oleh dosis siprofloksasin yang diberikan juga dipengaruhi nilai MIC awal dari bakteri E. coli. Hal tersebut disebabkan karena aksi farmakologi

${ }_{24} / \mathrm{MIC}$ dan $\mathrm{C}_{\max } / \mathrm{MIC}$. Semakin tinggi dosis siprofloksasin yang digunakan akan meningkatkan nilai parameter $\mathrm{AUC}_{0-24} / \mathrm{MIC}$. Oleh karena itu, untuk eradikasi 
optimal dibutuhkan dosis siprofloksasin yang semakin besar serta nilai MIC bakteri E. coli yang semakin kecil $^{6}$.

Berbagai sediaan herbal diketahui bermanfaat dalam pencegahan atau penyembuhan penyakit infeksi, contohnya cranberry (Vaccinium macrocarpon Ait.). Pemberian $72 \mathrm{mg} /$ hari proanthocyanidins (PACs) cranberry terstandar dalam bentuk bubuk dapat mencegah adhesi dan virulensi bakteri uropatogen $E$. coli. Namun herbal tersebut jarang ada di Indonesia, kalaupun ada harganya cukup mahal ${ }^{7}$. Salah satu herbal yang banyak didapatkan di Indonesia dan mempunyai aktivitas anti bakteri adalah tanaman manggis (Garcinia mangostana L.). Zat pada tanaman manggis yang mempunyai efek farmakologis sebagai anti bakteri adalah alfa mangostin ${ }^{8}$.

Resistensi bakteri terhadap fluorokuinolon terkait dengan regulatori gen yang mempengaruhi permeabilitas fluorokuinolon masuk ke dalam sel bakteri ${ }^{9}$. Efek alfa mangostin sendiri adalah bakterisida dengan mekanisme aksi merusak integritas membran sitoplasma bakteri sehingga komponen intrasel bakteri keluar. Aktivitas tersebut tergantung dosis ${ }^{10}$. Oleh karena itu, diharapkan alfa mangostin dapat mencegah resistensi dengan cara meningkatkan masuknya antibiotika siprofloksasin ke dalam sel bakteri. Tujuan dari penelitian ini adalah menguji efek pemberian kombinasi alfa mangostin dan siprofloksasin secara in vitro terhadap eradikasi bakteri uropatogen E. coli.

\section{METODE PENELITIAN}

\section{Populasi dan sampel penelitian}

Penelitian ini adalah penelitian eksperimental. Populasi penelitian adalah uropatogen $E$. coli yang didapatkan dari isolat pasien ISK RS Roemani Muhammadiyah Semarang. Sampel penelitian adalah tiga kelompok $E$. coli yang terdiri dari strain rentan, strain intermediat, dan strain resistan terhadap siprofloksasin. Penilaian kategori kerentanan E. coli mengacu pada EUCAST (2012), yaitu kategori rentan dengan nilai MIC d" 0,5 $\mathrm{mg} / \mathrm{L}$, strain $E$. coli intermediat dengan nilai MIC 0,5 - $1 \mathrm{mg} / \mathrm{L}$, dan strain E. coli resisten dengan nilai MIC $>1 \mathrm{mg} / \mathrm{L}^{11}$.

\section{Cara penelitian}

Untuk tahap pertama dilakukan isolasi uropatogen $E$. coli dari sampel urin pasien ISK di RS Roemani Muhammadiyah Semarang. Uropatogen E. coli yang didapatkan dari isolat klinik diuji terlebih dahulu nilai MIC sebelum perlakuan, menggunakan metode CLSI $(2012)^{12}$. Setelah didapatkan nilai MIC pada uropatogen E. coli, kemudian masing-masing dari ketiga kelompok strain uropatogen E. coli kemudian diberi perlakuan, yaitu (I) kelompok perlakuan menggunakan kadar siprofloksasin $\mathrm{C}_{\text {max }}$ pada dosis $500 \mathrm{mg}$, (II) kelompok perlakuan menggunakan kadar siprofloksasin $\mathrm{C}_{\max }$ pada dosis $750 \mathrm{mg}$, (III) kelompok perlakuan menggunakan kadar siprofloksasin $\mathrm{C}_{\max }$ pada dosis $500 \mathrm{mg}$ dan alfa mangostin, dan (IV) kelompok perlakuan menggunakan kadar siprofloksasin $\mathrm{C}_{\max }$ pada dosis $750 \mathrm{mg}$ dan alfa mangostin (skema gambar 1). Selain kelompok perlakuan, terdapat kelompok kontrol negatif (V), yang digunakan untuk melihat sterilitas media dan pelarut yang digunakan dalam penelitian.

Pemberian dosis alfa mangostin berdasar pada profil kadar maksimal dalam darah setelah pemberian jus manggis $60 \mathrm{~mL}$ per hari ${ }^{13}$. Penelitian tersebut menyatakan bahwa $60 \mathrm{~mL}$ jus manggis menyediakan \pm 3,07 mmol/L á-mangostin. Kadar maksimal dalam ámangostin dalam darah dicapai pada waktu 3,7 $\pm 2,4$ jam dengan kadar maksimal pada salah satu subyek penelitian sebesar $450 \mathrm{nmol} / \mathrm{L}$ atau setara dengan kadar $0,18 \mu \mathrm{g} / \mathrm{mL}$. Kadar tersebut yang digunakan sebagai acuan kelompok perlakuan (III) dan (IV). Kadar siprofloksasin perlakuan berdasar pada kadar maksimal siprofloksasin dalam darah setelah pemberian dosis siprofloksasin $500 \mathrm{mg}$ dan $750 \mathrm{mg}$, yaitu berturut-turut 2,4 dan $4,3 \mu \mathrm{g} / \mathrm{mL}^{14}$.

Setiap kelompok perlakuan pada semua strain uropatogen E. coli kemudian diinkubasi selama 2 jam pada suhu $37^{\circ} \mathrm{C}$. Jumlah koloni awal bakteri yang diinginkan sebelum perlakuan adalah $2 \times 10^{5} \mathrm{CFU} / \mathrm{mL}$. Jumlah koloni tersebut berdasarkan pada patogenesis ISK, yaitu jumlah minimal bakteri untuk menimbulkan gejala bakteriuria.

Setelah 2 jam inkubasi pertama, kemudian dilakukan prosedur hitung jumlah koloni untuk melihat efektivitas atau penurunan jumlah koloni bakteri dibandingkan 
awal sebelum perlakuan. Proses perhitungan jumlah koloni setelah 2 jam perlakuan dimulai dengan menggores sejumlah volume tertentu dari masingmasing perlakuan ke media agar Mueller Hinton Agar (MHA). Penggoresan sejumlah volume tertentu bakteri dalam media cair harus memperhatikan faktor pengenceran, karena perhitungan jumlah koloni dianggap valid jika jumlah koloni dalam media agar antara 30-300 koloni ${ }^{15}$.

\section{Pengolahan dan analisis data}

Data hasil sebelum dan sesudah perlakuan dianalisis. Data pengujian efek eradikasi kombinasi á-mangostin dan siprofloksasin adalah jumlah koloni bakteri. Penurunan jumlah koloni bakteri setelah 2 jam perlakuan dan inkubasi dilakukan dengan mengurangi jumlah koloni 2 jam setelah perlakuan dengan jumlah koloni bakteri uropatogen E. coli awal sebelum perlakuan. Perbedaan efek tiap perlakuan dianalisis dari masing-masing kategori strain uropatogen $E$. coli. Hal tersebut digunakan untuk melihat pengaruh dosis siprofloksasin dan atau diberikan secara kombinasi dengan á-mangostin pada tiap kategori strain uropatogen E. coli. Data di analisis dengan menggunakan uji t statistik. Data signifikansi ada atau tidaknya perbedaan pengaruh dosis perlakuan antar grup strain uropatogen E. coli juga dilakukan apabila terdapat signifikansi pada uji t-statistik tiap kategori strain uropatogen E.coli. Uji dilakukan menggunakan statistik analisis varian.

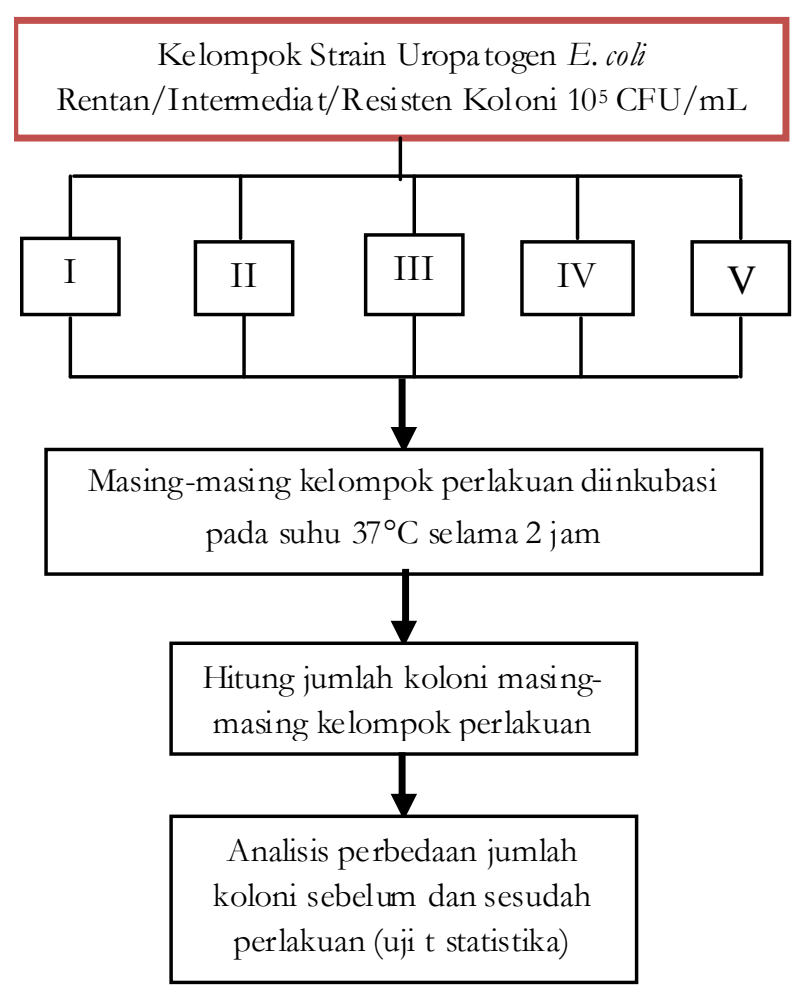

Gambar 1. Skema alur perlakuan I, II, III, IV, dan V pada masing-masing kelompok strain bakteri E. coli dengan tingkat kerentanan yang berbeda (Ket. (I) Siprofloksasin dosis $500 \mathrm{mg}$, (II) Siprofloksasin dosis $750 \mathrm{mg}$, (III) Siprofloksasin dosis $500 \mathrm{mg}$ dan alfa mangostin, (IV) Siprofloksasin dosis $750 \mathrm{mg}$ dan alfa mangostin.

\section{HASIL PENELITIAN}

Isolasi uropatogen $E$. coli dari sampel urin pasien ISK di RS Roemani Muhammadiyah Semarang.

Isolasi uropatogen E. coli dilakukan dari sampel urin pasien ISK RS Roemani Muhammadiyah Semarang.
Periode pengambilan sampel urin dilakukan dari 12 Maret hingga 7 Mei 2015. Total waktu pengambilan mendapatkan sampel urin adalah 13 hari dengan total 33 sampel urin. Dari 33 sampel urin yang didapatkan dari RS Roemani, hanya 3 (tiga) sampel urin yang positif terdapat uropatogen E.coli. Sampel uropatogen 
E. coli tersebut kemudian dikoding dengan kode sampel A, B, dan C.

\section{Penetapan kadar MIC uropatogen $E$. coli sebelum perlakuan.}

Berdasarkan hasil penetapan uji MIC maka sampel A dan B dikategorikan sebagai bakteri uropatogen $E$. coli resisten terhadap siprofloksasin karena nilai MIC lebih dari $1 \mathrm{mg} / \mathrm{L}(1 \mu \mathrm{g} / \mathrm{mL})$. Sampel A digunakan untuk penelitian, dengan nilai MIC $128 \mu \mathrm{g} / \mathrm{mL}$. Sampel $\mathrm{B}$ tidak digunakan karena nilai MIC lebih tinggi dari $128 \mu \mathrm{g} / \mathrm{mL}$. Sampel C merupakan strain uropatogen $E$. coli sensitif terhadap siprofloksasin dengan nilai MIC $0,008 \mu \mathrm{g} / \mathrm{mL}$ (nilai d" $0,5 \mu \mathrm{g} / \mathrm{mL}$ ). Untuk strain uropatogen $E$. coli kelompok intermediat terhadap siprofloksasin dibuat dengan memodifikasi jumlah koloni awal sampel $\mathrm{C}$, sehingga didapatkan nilai MIC $0,5 \mu \mathrm{g} / \mathrm{mL}$.

\section{Perlakuan pada uropatogen $E$. coli.}

Masing-masing dari ketiga kelompok strain uropatogen E. coli yaitu strain resisten (sampel A dengan nilai MIC $128 \mu \mathrm{g} / \mathrm{mL}$ ), strain intermediat (sampel D dengan nilai MIC $0,5 \mu \mathrm{g} / \mathrm{mL}$ ), dan strain sensitif terhadap siprofloksasin (sampel C dengan nilai MIC 0,008 $\mu \mathrm{g}$ / $\mathrm{mL}$ ) kemudian dibagi dalam lima kelompok perlakuan, yaitu (I) memberi perlakuan pada sejumlah masingmasing strain uropatogen $E$. coli dengan siprofloksasin sesuai kadar rata-rata $\mathrm{C}_{\max }$ subyek manusia pada dosis $500 \mathrm{mg}$ yaitu $2,4 \mu \mathrm{g} / \mathrm{mL}$; (II) memberi perlakuan pada sejumlah masing-masing strain uropatogen E. coli dengan siprofloksasin sesuai kadar rata-rata $\mathrm{C}_{\max }$ pada dosis $750 \mathrm{mg}$ yaitu $4,3 \mu \mathrm{g} / \mathrm{mL}$, (III) memberi perlakuan pada sejumlah masing-masing strain uropatogen $E$. coli dengan siprofloksasin sesuai kadar rata-rata $\mathrm{C}_{\text {max }}$ pada dosis $500 \mathrm{mg}(2,4 \mu \mathrm{g} / \mathrm{mL})$ dan á-mangostin sesuai kadar maksimal subyek manusia setelah pemberian 60 $\mathrm{mL}$ jus manggis $(0,18 \mu \mathrm{g} / \mathrm{mL})$, (IV) memberi perlakuan pada sejumlah masing-masing strain uropatogen $E$. coli dengan siprofloksasin sesuai kadar rata-rata $\mathrm{C}_{\max }$ pada dosis $750 \mathrm{mg}(4,3 \mu \mathrm{g} / \mathrm{mL})$ dan á-mangostin sesuai kadar maksimal subyek manusia setelah pemberian 60 $\mathrm{mL}$ jus manggis $(0,18 \mu \mathrm{g} / \mathrm{mL})$, serta (V) kelompok kontrol negatif.
Penelitian ini melihat efek terapi masing-masing perlakuan dengan menghitung penurunan jumlah koloni setelah 2 jam perlakuan atau inkubasi. Pengukuran efek terapi masing-masing perlakuan pada 2 jam setelah perlakuan untuk melihat seberapa cepat perlakuan dapat membunuh bakteri di awal pemberian. Uropatogen E. coli atau strain E. coli pada umumnya dapat bermutasi dan berkembang menjadi resisten dengan cepat, terutama apabila diberikan dosis obat yang subterapeutik $^{16}$.

Penurunan jumlah koloni setelah 2 jam perlakuan dihitung dengan mengurangi jumlah koloni awal perlakuan dengan jumlah koloni 2 jam setelah perlakuan. Jumlah koloni 2 jam setelah perlakuan dihitung dengan cara mengambil sejumlah volume tertentu dari masing-masing sampel perlakuan dan digoreskan di cawan petri berisi media MHA.

Beberapa metode dapat digunakan untuk menghitung sel bakteri suatu sampel, antara lain (1) viable count, hanya menghitung sel yang aktif dan hidup secara metabolik, (2) total count, menghitung sel bakteri hidup dan mati, (3) direct count, menghitung jumlah koloni secara langsung, serta (4) indirect count, menghitung jumlah sel misalnya berdasarkan hamburan sel yang dikultur (pembacaan absorbansi) dengan spektrofotometer. Untuk perhitungan jumlah koloni 2 jam setelah perlakuan menggunakan metode viable count, dengan asumsi mengukur sel yang hidup yang akan tumbuh ketika dikultur pada suatu media yang sesuai.

Jika melihat pada hasil tabel 1 maka dapat dikatakan bahwa seluruh perlakuan I hingga IV tidak dapat membunuh bakteri pada awal 2 jam perlakuan. Nilai minus menunjukkan adanya kecenderungan peningkatan jumlah bakteri di awal 2 jam perlakuan. Nilai MIC dari uropatogen E. coli sampel A adalah 128 $\mu \mathrm{g} / \mathrm{mL}$, lebih besar daripada nilai kadar siprofloksasin yang diberikan pada perlakuan I $(2,4 \mu \mathrm{g} / \mathrm{mL})$ dan perlakuan II $(4,3 \mu \mathrm{g} / \mathrm{mL})$. 
Tabel 1. Nilai rata-rata, standar deviasi, dan koefisien variasi penurunan jumlah log koloni sampel A setelah 2 jam perlakuan pada masing-masing kelompok perlakuan

Kelompok Perlakuan Rata-Rata \pm SD Koefisien Variasi (\%)

\begin{tabular}{ccc}
\hline $\begin{array}{c}\text { Kelompok } \\
\text { Perlakuan }\end{array}$ & $\begin{array}{c}\text { Rata-Rata } \pm \\
\text { SD }\end{array}$ & $\begin{array}{c}\text { Koefisien Variasi } \\
(\%)\end{array}$ \\
\hline I & $-0,278 \pm 0,03$ & 0,11 \\
II & $-0,222 \pm 0,13$ & 0,61 \\
III & $-0,140 \pm 0,14$ & 1,02 \\
IV & $-0,182 \pm 0,26$ & 1,45 \\
\hline
\end{tabular}

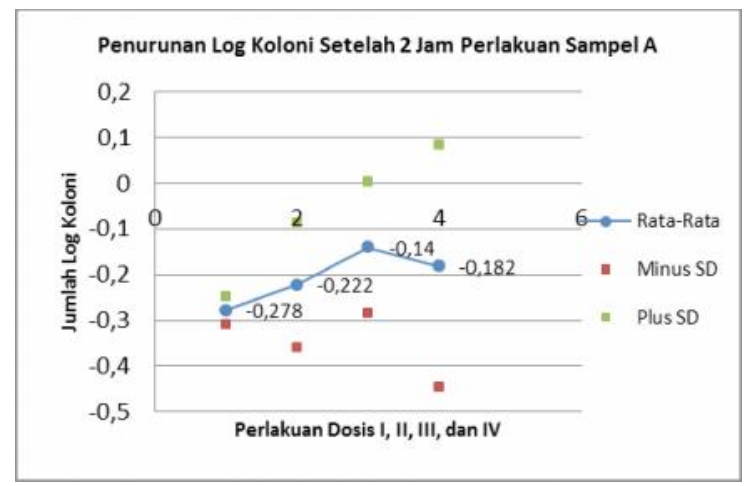

Gambar 2. Grafik perbedaan penurunan jumlah koloni (rata-rata $\pm \mathrm{SD}$ ) setelah 2 jam perlakuan pada sampel A. Kelompok perlakuan I $(-0,278)$, II $(-0,222)$, III ($0,140)$, dan IV $(-0,182)$

Nilai rata-rata pertambahan jumlah koloni pada kelompok perlakuan III dan IV berbeda dibandingkan kelompok perlakuan I dan II, namun perbedaan tersebut tidak bermakna karena rentang deviasi yang cukup besar. Meskipun demikian, penambahan á-mangostin pada pemberian siprofloksasin di kelompok perlakuan III dan IV, menunjukkan terdapat manfaat pemberian ámangostin dalam mencegah multiplikasi atau pertumbuhan uropatogen E. coli sampel A (Gambar 2).

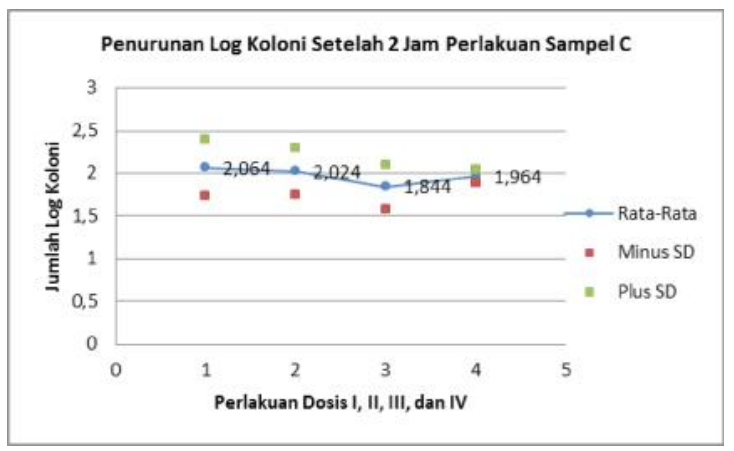

Gambar 3. Grafik perbedaan penurunan jumlah koloni (rata-rata $\pm \mathrm{SD}$ ) setelah 2 jam perlakuan pada sampel C. Kelompok perlakuan I $(2,064)$, II $(2,024)$, III $(1,844)$, dan IV $(1,964)$

Pada sampel C, terdapat penurunan jumlah koloni pada seluruh kelompok perlakuan setelah diinkubasi selama 2 jam. Jika dilihat dari nilai rata-rata penurunan jumlah koloni sampel C, maka tidak terdapat perbedaan antara seluruh kelompok perlakuan (Gambar 3 dan Tabel 2).

Tabel 2. Nilai rata-rata, standar deviasi, dan koefisien variasi penurunan jumlah log koloni sampel $\mathrm{C}$ setelah 2 jam perlakuan pada masing-masing kelompok perlakuan

Kelompok Perlakuan Rata-Rata \pm SD Koefisien Variasi (\%)

\begin{tabular}{ccc}
\hline $\begin{array}{c}\text { Kelompok } \\
\text { Perlakuan }\end{array}$ & $\begin{array}{c}\text { Rata-Rata } \pm \\
\text { SD }\end{array}$ & $\begin{array}{c}\text { Koefisien Variasi } \\
(\%)\end{array}$ \\
\hline I & $2,064 \pm 0,33$ & 0,16 \\
II & $2,024 \pm 0,27$ & 0,14 \\
III & $1,844 \pm 0,26$ & 0,14 \\
IV & $1,964 \pm 0,08$ & 0,04 \\
\hline
\end{tabular}

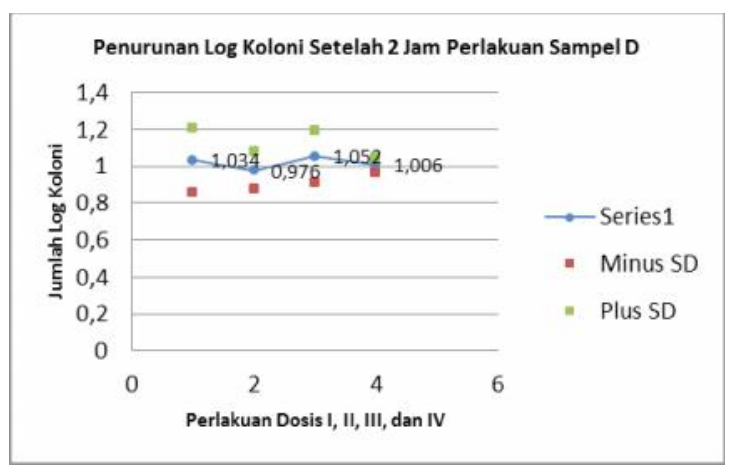

Gambar 4. Grafik perbedaan penurunan koloni (ratarata \pm SD) setelah 2 jam perlakuan pada sampel D. Kelompok perlakuan I (1,034), II (0,976), III $(1,052)$, dan IV $(1,006)$ 
Untuk sampel D, juga terlihat adanya penurunan jumlah koloni bakteri pada semua kelompok perlakuan pada inkubasi 2 jam pertama. Namun penambahan ámangostin tidak meningkatkan penurunan jumlah koloni bakteri sampel D (Gambar 4 dan Tabel 3). Jika dibandingkan dengan sampel $\mathrm{C}$, maka penurunan jumlah koloni bakteri sampel $\mathrm{C}$ lebih besar dibandingkan sampel D. Hal tersebut dapat disebabkan karena nilai MIC sampel C $(0,008 \mu \mathrm{g} / \mathrm{mL})$ lebih kecil dari nilai MIC sampel D $(0,5 \mu \mathrm{g} / \mathrm{mL})$.

Tabel 3. Nilai rata-rata, standar deviasi, dan koefisien variasi penurunan jumlah log koloni sampel D setelah 2 jam perlakuan pada masing-masing kelompok perlakuan

Kelompok Perlakuan Rata-Rata \pm SD Koefisien Variasi $(\%)$

\begin{tabular}{ccc}
\hline $\begin{array}{c}\text { Kelompok } \\
\text { Perlakuan }\end{array}$ & $\begin{array}{c}\text { Rata-Rata } \pm \\
\text { SD }\end{array}$ & $\begin{array}{c}\text { Koefisien Variasi } \\
(\%)\end{array}$ \\
\hline I & $1,034 \pm 0,17$ & 0,17 \\
II & $0,976 \pm 0,10$ & 0,10 \\
III & $1,052 \pm 0,14$ & 0,13 \\
IV & $1,006 \pm 0,04$ & 0,04 \\
\hline
\end{tabular}

Untuk melihat perbedaan penurunan jumlah koloni setelah 2 jam perlakuan pada tiap kelompok strain uropatogen $E$. coli, dapat dilihat dari gambar 5 berikut:

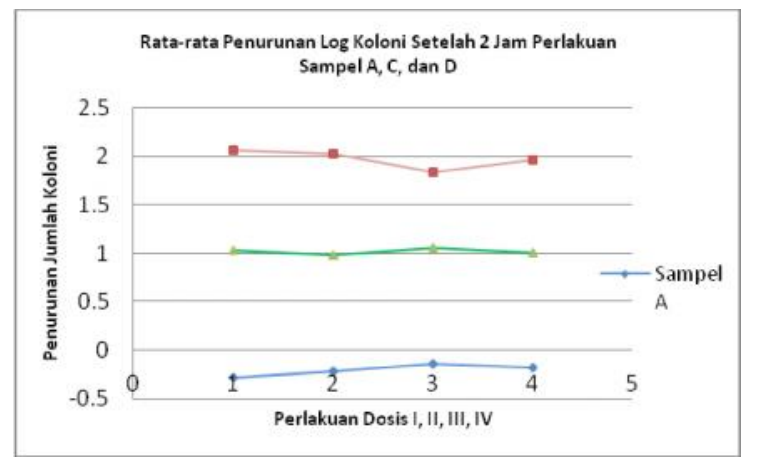

Gambar 5. Rata-rata penurunan jumlah koloni uropatogen E. coli setelah 2 jam perlakuan, sampel A, C, dan D.

\section{PEMBAHASAN}

Penggunaan kombinasi antibiotik bertujuan mengurangi dosis masing-masing obat, sehingga diharapkan kejadian efek obat yang tidak diinginkan (adverse drug reaction) dari kedua antibiotik akan berkurang. Selain itu, kombinasi antibiotik akan sangat bermanfaat apabila salah satu obat dan bekerja dengan menghambat resistensi suatu bakteri terhadap antibiotik yang lain. Contoh yang paling baik adalah asam klavulanat yang diberikan bersama dengan amoksisilin, dengan tujuan mengurangi resistensi bakteri terhadap amoksisilin. Asam klavulanat berguna untuh mencegah pembentukan enzim penisilinase yang akan merusak amoksisilin.

Penelitian mengenai kombinasi antibiotik dengan beberapa ekstrak kasar (crude extract) atau isolat murni tanaman mulai dilakukan untuk menemukan kombinasi yang baik seperti pada penggunaan amoksisilin dan asam klavulanat. Hal tersebut dilakukan untuk optimalisasi penggunaan antibiotik yang ada, serta untuk pencegahan resistensi bakteri terhadap antibiotik yang telah tersedia ${ }^{17}$.

Penelitian ini bertujuan untuk melihat apakah kombinasi á-mangsotin dan siprofloksasin lebih efektif dibandingkan penggunaan siprofloksasin saja. Secara teori, á-mangostin mempunyai target pada membran bakteri, yang menghasilkan aksi bakterisidal cepat. Efek pada membran bakteri tersebut juga diharapkan dapat mengalihkan resistansi dengan cara menurunkan kemungkinan mutasi terkait struktur membran bakteri ${ }^{10}$. Namun pada penelitian ini efek á-mangostin tidak terlihat membantu dari efek siprofloksasin terhadap uropatogen E. coli. Pengurangan jumlah koloni bakteri 2 jam setelah perlakuan pada bakteri yang masih sensitif dan intermediat terhadap siprofloksasin tidak berbeda bermakna, baik pada kelompok perlakuan siprofloksasin saja atau pada kelompok perlakuan kombinasi ámangostin dan siprofloksasin (Gambar 3 dan 4).

Ibrahim et al (2014) melakukan penelitian menggunakan kombinasi á-mangostin dengan enam macam antibiotik yaitu ampisilin, doksisiklin, penisilin G, streptomisin, tetrasiklin, dan nistatin. Uji pemberian kombinasi ámangostin dengan salah satu antibiotik tersebut dilakukan telah dilakukan pada bakteri Gram $+(S$. aureus dan B. cereus) serta bakteri Gram - ( $P$. aeruginosa dan E. coli). Hasil menunjukkan bahwa tidak terdapat interaksi yang mengguntungkan antara á-mangostin dan antibiotik dalam membunuh bakteri. Senyawa á-mangostin sendiri juga tidak aktif terhadap bakteri dibandingkan dengan ekstrak kasar kulit manggis untuk membunuh bakteri. Hal tersebut dapat 
disebabkan karena pada ekstrak kasar terdapat senyawa lain yang dapat meningkatkan efek dari á-mangostin ${ }^{16}$.

Penelitian lain mengenai efek á-mangostin pada pertumbuhan bakteri telah dilakukan. Bakteri Gram + dinyatakan lebih sensitif terhadap á-mangostin dibandingkan bakteri Gram - ${ }^{10}$. Bakteri Gram - seperti Klebsiella spp, Proteus mirabilis, dan E. coli dikatakan hanya moderat rentan terhadap senyawa xanthon, dibandingkan bakteri Gram $+{ }^{18}$. Isolat á-mangostin dari hasil ekstraksi etil asetat Garcinia mangostana ditemukan aktif terhadap $S$. aureus dan Mycobacterium tuberculosis dengan nilai MIC 3,2 $\mu \mathrm{g} / \mathrm{mL}$ dan 1,5 $\mu \mathrm{g}$ / mL. Namun pada penelitian tersebut disebutkan bahwa á-mangostin tidak aktif terhadap $E$. coli dengan nilai IC50 > $200 \mu \mathrm{g} / \mathrm{mL}^{19}$.

Penelitian menggunakan ekstrak etanol dan ekstrak encer dari kulit Garcinia mangostana linn untuk menentukan nilai MIC dan MBC terhadap E. coli. Hasil menunjukkan nilai MIC dan MBC ekstrak etanol Garcinia mangostana Linn terhadap E. coli adalah $2000 \mu \mathrm{g} / \mathrm{mL}$, nilai MIC dan MBC ekstrak encer terhadap E. coli adalah $4000 \mu \mathrm{g} / \mathrm{mL}^{20}$.

Penelitian lain dari penggunaan ekstrak metanol Garcinia mangostana, didapatkan zona hambat pada penggunaan ekstrak $500 \mu \mathrm{g} / \mathrm{mL}$ pada bakteri Gram + (Bacillus subtilis, S. aureus, S. faecalis) dan tidak terdapat zona hambat pada bakteri Gram - (E. coli dan P. aeruginosa $)^{21}$.

Melihat hasil penelitian, tidak terlihat efek á-mangostin pada penurunan jumlah koloni 2 jam perlakuan bakteri uropatogen $E$. coli sensitif atau intermediat siprofloksasin. Namun pada bakteri uropatogen $E$. coli resisten terdapat pertumbuhan atau multiplikasi bakteri yang lebih lambat pada kelompok perlakuan kombinasi á-mangostin dan siprofloksasin dibandingkan kelompok perlakuan siprofloksasin saja (Gambar 2). Hal tersebut didukung penelitian Rahmawati (2010) bahwa kombinasi ekstrak kulit manggis yang mengandung á-mangostin dengan siprofloksasin dapat menghambat $E$. coli multiresiten jika dibandingkan dengan penggunaan tunggal siprofloksasin atau ekstrak kulit manggis saja ${ }^{22}$.

Untuk itu diperlukan penelitian lanjutan, salah satunya dengan meningkatkan kadar á-mangostin yang digunakan. Peningkatan kadar akan meningkatkan resiko toksisitas apabila digunakan secara in vivo. Meskipun salah satu uji sitotoksik, dilakukan pada sel gingival fibroblast manusia selama 6 jam menggunakan ámangostin kadar $4000 \mu \mathrm{g} / \mathrm{mL}$ terbukti tidak toksik ${ }^{23}$.

Pelarut á-mangostin yang digunakan pada penelitian ini adalah metanol. Hampir semua pelarut non polar atau pelarut organik yang biasa digunakan pada industri farmasi dapat digunakan untuk melarutkan á-mangostin, contohnya etanol, metanol, propilen glikol, dimetilformamide, aseton, atau heksan. Pada penelitian ini dipilih metanol, disesuaikan dengan petunjuk pelarutan di label kemasan á-mangostin. Metanol sendiri dikategorikan sebagai pelarut kelas 2 oleh Food and Drug Administration (FDA), yang penggunaannya dibatasi di industri farmasi karena cukup toksik. Kadar metanol maksimum harian adalah 3000 ppm atau setara dengan $3 \mathrm{mg}$ metanol dalam tiap $\mathrm{mL}$, setara dengan 380 $\mu \mathrm{L}$ metanol dalam 100,0 $\mathrm{mL}$ larutan pengencer (akuades). Namun menurut petunjuk pelarutan dalam kemasan, á-mangostin dilarutkan dalam metanol dengan kadar $1 \mathrm{mg} / \mathrm{mL}$. Penggunaan metanol dalam penelitian $1000 \mu \mathrm{L}$ dalam 100,0 larutan pengencer (akuades) atau lebih tinggi tiga kali lipat dibandingkan batas maksimal harian penggunaan metanol ${ }^{24}$.

Selain itu, meskipun etanol dapat digunakan sebagai pelarut yang lebih aman, namun efek bakterisidal etanol lebih besar daripada metanol dan dikhawatirkan mengganggu perlakuan. Metanol merupakan bakterisidal terlemah dari golongan alkohol ${ }^{25}$.

\section{KESIMPULAN}

Pemberian kombinasi siprofloksain dan á-mangostin dapat mencegah pertumbuhan bakteri uropatogen $E$. coli pada strain resisten (nilai MIC $128 \mu \mathrm{g} / \mathrm{mL}$ ) dibandingkan dengan pemberian siprofloksasin saja. Namun untuk uropatogen E. coli sensitif (MIC 0,008 $\mu \mathrm{g} / \mathrm{mL}$ ) dan intermediat (MIC $0,5 \mu \mathrm{g} / \mathrm{mL}$ ), tidak terdapat perbedaan efek penurunan jumlah koloni atau eradikasi antara pemberian kombinasi siprofloksasin dan ámangostin dengan pemberian siproflokasin tunggal. 


\section{DAFTAR PUSTAKA}

1. Drussano, G.L. 2007. Pharmacokinetics and pharmacodynamics of antimicrobial. Clin Infect Dis. 45:589-595.

2. Hooton, TM. 2000. Pathogenesis of urinary track infections: an update. Journal of antimicrobial chemotherapy 46. Suppl. S1:1-7

3. Mandal J, Acharya S, Buddhapriya D, Parija SC. 2012. Antibiotic resistance pattern among common bacterial uropathogens with a special reference to ciprofloxacin resistant Escherichia coli.

4. Gloede, J., Scheerans, C., Derendorf, H., and Kloft, C. 2010. In vitro pharmacodynamic models to determine the effect of antibacterial drugs. $J$ Antimicrob Chemother 65:186-201.

5. Rakhmawatie MD, Mustofa. 2012. Efek perbedaan dosis siprofloksasin pada resistensi uropatogen Escherichia coli: simulasi model kinetika in vitro. Tersedia dalam etd.ugm.ac.id.

6. Olofsson, S.K., Marcusson, L.L., Stromback, A., Hughes, D., and Cars, O. 2007. Dose related selection of fluoroquinolone resistant escherichia coli. $J$ Antimicrob Chemother 60:795-801.

7. Howell AB., Botto H., Combescure C., Blanc-Pottard A., Gausa L., Matsumoto T., et al. 2010. Dosage effect on uropathogenic Escherichia coli antiadhesion activity in urine following consumption of cranberry powder standardized for proanthocyanidin content: a multicenteric randomized double blind study. BMC (Biomedcentral) Infectious Disease Vol.10:94

8. Chaverri JP, Rodriguez NC, Ibarra MO, and Rojas JMP. 2008. Review Medicinal properties of mangosteen (Garcinia mangostana). Food and Chemical Toxicology Vol. 46: 3227-3239

9. Allou, N., Cambau, E., Massias, L., Chau, F., and Fantin, B., 2009. Impact of low-level resistance to fluoroquinolones due to qnrA1 and qnrS1 genes or a gyrA mutation on ciproûoxacin bactericidal activity in a murine model of Escherichia coli urinary tract infection. Antimicrob Agents Chemother 53(10):42924297.
10.Koh JJ, Qiu S, Zou H, LakshminarayananR, Li J, Zhou X, et al. 2013. Rapid bactericidal action of alpha-mangostin against MRSA as an outcome of membrane targeting. Biochimica et Biophysica Acta Vol 1828(2): 834-44

11.EUCAST. 2012. Breakpoint tables for interpretation of MIC and zone diameters. European Committee on Antimicrobial Susceptibility Testing. Diakses 11 Maret 2012 dari www.eucast.org/clinical_breakpoints/

12.CLSI. 2012. Methods for dilution antimicrobial susceptibility test for bacteria that grow aerobically; approved standard ninth edition. CLSI M07-09 Vol. 32(2).

13.Chitchumroonchokchai C, Riedl KM, Suksumrarn S, Clinton SK, Kinghorn AD, and Faila ML. 2012. Xanthones in mangosteen juice are absorbed and partially conjugated by healthy adults. Journal of Nutrition Vol 142(4): 675-680

14.FDA. 2011. Ciprofloxacin. Ciprofloxacin Official FDA Information, Side Effect, and Uses. Diakses 15 September 2011 dari http://www.drugs.com/pro/ ciprofloxacin.html

15.Fardiaz, S. 1992. Mikro pangan I. Jakarta: PT. Gramedia Pustaka.

16.Van der Horst, MA., Schuurmans, JM., Smid, MC., Koenders, BB., and ter Kuile, BH. 2011. De novo acquisition of resistance to three antibiotic by Escherichia coli. Microb. Drug Resist, Vol. 17(2): 141-7

17.Ibrahim NHS, Taher M, Susanti D, Amroudine MZAM, dan Ahmed QU. 2014. Direct and indirect antimicrobial effects of á-mangostin on pathogenic microorganism. Journal of Coastal Life Medicine, Vol. 2(1): 70-5

18.Ibrahim MY, Hashim NM, Mariod AA, Mohan S, Abdulla MA, Abdelwahab SI, dan Arbab IA. 2014. Review: á-mangostin from Garcinia mangostana Linn: An updated review of its pharmacological properties. 